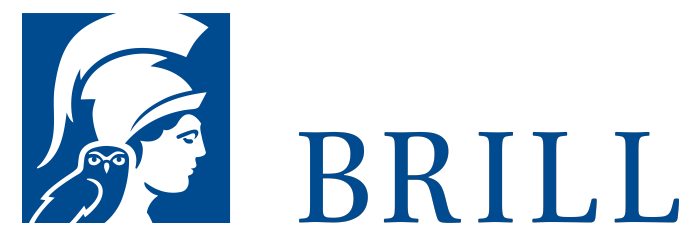

\title{
Mehr als ein Gespräch
}

Zur Dialogik von Gebet und Offenbarung in jüdischer und christlicher Liturgie

Author: Peter Ebenbauer

Liturgie ist Gespräch, Kommunikation zwischen Gott und den Menschen, und sie ist zugleich mehr als das: Jeder Gottesdienst bringt normative Aspekte ins Spiel, die über Gott und die Menschen sowie über deren Beziehungen zueinander etwas festhalten, das jedem Gespräch vorausliegt. Auf der Basis der seit dem Zweiten Vatikanischen Konzil erneuerten Israeltheologie der christlichen Kirchen wird untersucht, wie sich an spezifischen Merkmalen liturgischen Betens und liturgischer Verkündigung des Wortes Gottes fundamentale Gemeinsamkeiten und spezifische Differenzen zwischen jüdischem und christlichem Glauben zeigen. Aus den gewonnenen Erkenntnissen werden Schlüsse für die zukünftige Entwicklung christlicher Liturgie sowie für den christlichjüdischen Dialog gezogen. Gegen aktuelle restaurative Tendenzen eröffnet diese Studie den Weg zu einer vertieften christlich-jüdischen Partnerschaft aus und in ihren je eigenen gottesdienstlichen Traditionen. Der Autor: PD Dr. Peter Ebenbauer, geb. 1966, Studium der Katholischen Theologie in Graz und München, wissenschaftlicher Mitarbeiter am Institut für Liturgiewissenschaft, Christliche Kunst und Hymnologie der Katholisch-Theologischen Fakultät in Graz, Privatdozent für Liturgiewissenschaft an der Katholisch-Theologischen Fakultät in Bonn, Lehrbeauftragter für das Fach Liturgik am Institut für Kirchenmusik und Orgel der Kunstuniversität Graz.

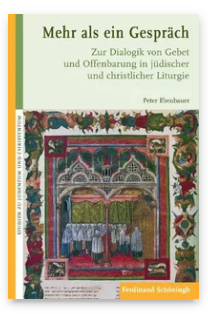

Pages: 320

Seiten

Language:

German

Subjects:

General,

Theology and

World

Christianity,

Philosophy,

Theology \&

Science, Jewish

Studies

Publisher: Brill |

Schöningh

Series:

Studien zu

Judentum und

Christentum

E-Book (PDF)

Released online:

13 Jan 2020

ISBN: 978-3-

657-76872-1

List price

USD $\$ 63.00$

Paperback

Publication date:

28 Oct 2009

ISBN: $97^{8-3-}$

506-76872-8

List price

USD $\$ 63.00$ 
For more information see brill.com

Order information: Order online at brill.com +44330 333 0049 | customerservices@brill.com Submission information: brill.com/authors

Titles published by Brill | Fink, Brill | mentis or Brill | Schöningh: +49(o)715413279216| brill@brocom.de 